\title{
The Clinical Effect of Bipolar Transurethral Resection in Saline of Benign Prostate Hyperplasia with Long Term Follow-Up
}

\author{
Sompol Permpongkosol \\ Department of Surgery, Faculty of Medicine, Ramathibodi Hospital, Mahidol University, Bangkok, Thailand \\ Email: sompolpermpong@gmail.com
}

How to cite this paper: Permpongkosol, S. (2018) The Clinical Effect of Bipolar Transurethral Resection in Saline of Benign Prostate Hyperplasia with Long Term Follow-Up. Open Journal of Urology, 8, 108-117.

https://doi.org/10.4236/oju.2018.84012

Received: March 14, 2018

Accepted: April 23, 2018

Published: April 26, 2018

Copyright $\odot 2018$ by author and Scientific Research Publishing Inc. This work is licensed under the Creative Commons Attribution International License (CC BY 4.0).

http://creativecommons.org/licenses/by/4.0/

\begin{abstract}
Transurethral resection of the prostate (TURP) is considered as the gold standard for the management of bladder outlet obstruction due to benign prostatic hyperplasia (BPH). Long-term follow-up of the clinical effect of bipolar transurethral resection of the prostate (B-TURP) in saline for BPH is required. Objective: To compare, with long term follow-up, the efficacy and safety of B-TURP in the treatment of BPH with prostate gland volumes of $<45$ $\mathrm{ml},>45 \mathrm{ml}$, and larger than $60 \mathrm{ml}$. Materials and Methods: From January 2006 to December 2016, 318 patients with a mean age of $69.45 \pm 8.37$ years and a median prostate volume of $42 \mathrm{~cm}^{3}$ (56.51 - 32.47) were treated with B-TURP by single urologist (SP) at the Division of Urology, Department of Surgery, Faculty of Medicine, Ramathibodi Hospital, Mahidol University. We retrospectively analyzed the perioperative status of patients' status follow-up for at least 6 months and up to 5 years. Post-void residual (PVR) and maximum flow rate (Qmax) were assessed preoperatively and postoperatively. Operative time, length of catheterization and hospitalization and complications were all reported. Results: The main indication for B-TURP was failure of medication (81.13\%). Perioperative results showed no statistical significance among the groups in terms of catheterization days and the hospitalization length. During the follow-up, the improvement of postoperative parameters was compared with preoperative subscales, at different periods from baseline and after $24,36,48$, and 60 months post treatment. PSA, Q max, PVR, and average flow rate were significantly different from pre-operation data $(p<$ 0.005). Regarding TURP complications, significant differences were observed in relation to transient incontinence (5.87\%), urinary tract infection $(2.5 \%)$, urinary retention/catheterization (1.57\%), contracture of bladder neck (4.4\%), urethral strictures $(4.09 \%)$, recurrence of BPH (2.83\%), hypotonic bladder $(0.6 \%)$ and erectile dysfunction (7.8\%). No TUR syndrome or secondary hemorrhage was recorded in the study. Interestingly, complications in patients
\end{abstract}


on ongoing oral anticoagulation were not found. Conclusion: With long-term follow-up, B-TURP is a safe and effective technique for BPH management with prostate gland $<45 \mathrm{ml},>45 \mathrm{ml}$ and larger than $60 \mathrm{ml}$.

\section{Keywords}

Lower Urinary Tract Symptoms (LUTS), Benign Prostatic Hyperplasia (BPH), Transurethral Resection of Prostate (TURP), Bipolar TURP (B-TURP)

\section{Introduction}

Despite the rise of new minimally invasive technologies, transurethral resection of prostate (TURP) is the gold standard of surgical treatment for bothersome moderate severe lower urinary tract symptoms (LUTS) secondary to BPH [1] [2] [3]. The three main reasons for the continued popularity of TURP are a robust, simple technique; and, until now, unsurpassed efficacy; and, with regard to the risk-benefit ratio, a low morbidity [4].

Monopolar (M-TURP) and bipolar (B-TURP) are safe, effective techniques and both are equally widely used in surgical treatment for $\mathrm{BPH}$ management [5]. Although M-TURP efficacy in prostate resection is established, potential perioperative complications and associated costs remain a concern [6]. In contrast, bipolar TURP is considered more efficacious and has a better clinical outcome in comparison with M-TURP [7]. In this study, B-TURP reported a significant reduction of related complications [3] [8] [9]. B-TURP coupled with $0.9 \%$ sodium chloride has minimal effects on serum sodium levels, compared with M-TURP [5]. Interestingly, Madduri et al. concluded that B-TURP is the new gold standard, since urologists prefer to operate on larger prostates using B-TURP, which definitely reduces the incidence of bleeding and hyponatremia [10]. However, many studies are conflicting regarding the merits of B-TURP over M-TURP. [10] B-TURP is associated with high complication rates, especially secondary hemorrhage [11] [12], and M-TURP should be used if surgeons want to save time [7].

Moreover, present practice demonstrates the majority of a representative group of the Endourological Society members perform TURP in patients on ongoing oral anticoagulation (OA) [13]. To our knowledge, no report related to $\mathrm{B}$-TURP in patients on ongoing oral anticoagulation (OA) in a long-term follow-up has been published. Therefore, in this study, we evaluated and compared the efficacy and safety of B-TURP in the treatment of BPH with prostate gland < $45 \mathrm{ml},>45 \mathrm{ml}$ and larger than $60 \mathrm{ml}$ and with long term follow-up. We also evaluated the factors associated with complications especially secondary hemorrhage after B-TURP in patients on ongoing OA.

\section{Material and Methods}

From January 2006 to December 2016, 318 Patients with LUTS due to BPH un- 
derwent B-TURP by single urologist (SP) at the Division of Urology, Department of Surgery, Faculty of Medicine, Ramathibodi Hospital, Mahidol University. Patients were evaluated preoperatively by full detailed history, routine preoperative investigation, digital rectal examination (DRE), serum prostate-specific antigen (PSA), transrectal ultrasonography (TRUS), maximum flow rates (Qmax) and Post-void residual (PVR). The exclusion criteria included urethral stricture disease, known history of neurogenic bladder dysfunction, active urinary tract infection, previous prostate, bladder and/or urethral surgery or bladder cancer.

Patients underwent standard B-TURP (Olympus Medical, Tokyo, Japan) performed by single urologist (SP) using the same surgical technique [14]. A $26 \mathrm{Fr}$ Karl Storz (Tuttlingen, Germany) resectoscope was used with pre-warmed normal saline solution as an irrigant with a continuous-flow setup for clear vision during the procedure. The middle lobe was first resected and an excavation up to the surgical capsule was formed. After that, the side lobes and ventral parts of the gland were resected. Finally, the apical parts of the gland were resected. At the end of the B-TURP, a three-way 22-F Foley catheter was inserted for postoperative continuous bladder irrigation with saline until the urine became clear. Then, the Foley catheter was removed and the patients were discharged when voiding was satisfactory.

We retrospectively analyzed the perioperative status of patients by follow-up for at least 6 months and up to 5 years. Postoperative parameters were evaluated and the patients were reassessed at 24,36, 48 and 60-month follow-ups with the same examinations. PVR and Qmax were assessed preoperatively and postoperatively. Operative time, length of catheterization and hospitalization and complications were all reported. All data were entered in SPSS-17.0 software. A $p$-value less than 0.05 was considered as significant.

\section{Results}

At the beginning of the study, there were 318 patients. The mean age of the patients was $69.45 \pm 8.37$ years. Table 1 shows the baseline characteristics of patients who underwent B-TURP. Hypertension (57.86\%) was the most common underlying disease of the patients. Indications for B-TURP included failure of medication $(81.13 \%)$, acute urinary retention (11.95\%) recurrence of UTI (3.77\%), recurrence of hematuria (1.57\%) and bladder stones (1.57\%). B-TURP was performed in 27 patients $(8.49 \%)$ on ongoing OA. The major anesthesia technique was spinal block (70.44\%).

Table 2 shows the evaluation of preoperative parameters. The mean postoperative irrigation volume was $15,000 \mathrm{ml}$. The median duration of resection in bipolar TURP was 80 minutes (102.5 - 65.0). Median hospital stay was 3 days (4 - 3) and median indwelling catheterization time was 3 days (4-3). The median prostate volume and the median amount of resected tissue were $46 \mathrm{ml}$ (56.51 32.47), and $8.5 \mathrm{gm}(13$ - 5), respectively. Median blood loss was $50 \mathrm{ml}(100-10)$ 
Table 1. Baseline characteristic of patients underwent B-TURP $(\mathrm{N}=318)$.

\begin{tabular}{|c|c|c|}
\hline Variable & Mean \pm SD & Range \\
\hline Age (Years) & $69.45 \pm 8.37$ & $36-88$ \\
\hline BMI & $24.38 \pm 3.42$ & $13.35-35.76$ \\
\hline Underlying & $\mathrm{N}$ & $(\%)$ \\
\hline Hypertension & 184 & 57.86 \\
\hline Dyslipidemia & 126 & 39.62 \\
\hline Diabetic Mellitus & 82 & 25.79 \\
\hline Inguinal Hernia & 8 & 2.5 \\
\hline CAD & 6 & 1.886 \\
\hline Parkinsonism & 3 & 0.943 \\
\hline Erectile dysfunction & 58 & 18.24 \\
\hline \multicolumn{3}{|l|}{ Indication for TURP } \\
\hline Failure of medication & 258 & 81.13 \\
\hline Acute Urinary Retention & 38 & 11.95 \\
\hline Recurrence of UTI & 12 & 3.774 \\
\hline Recurrence of hematuria & 5 & 1.572 \\
\hline Bladder stones & 5 & 1.572 \\
\hline On ASA & 27 & 8.491 \\
\hline \multicolumn{3}{|l|}{ Anesthesia technique } \\
\hline Spinal Block & 224 & 70.44 \\
\hline General Anesthesia & 11 & 3.459 \\
\hline
\end{tabular}

B-TURP = Bipolar Transurethral resection of prostate; $\mathrm{BMI}=$ Body Mass Index; CAD = Cardiovascular disease; UTI = Urinary tract infection; ASA = acetylsalicylic acid.

Table 2. Preoperative data.

\begin{tabular}{ccc}
\hline Variables & Median & IQR (Q3 - Q1) \\
\hline Irrigation Volume (ml) & 15,000 & $12,500(22,000-9500)$ \\
Operative time (min) & 80 & $37.50(102.50-65.00)$ \\
Duration of catheter (days) & 3 & $1(4-3)$ \\
Hospital stay (days) range & 3 & $1(4-3)$ \\
\hline
\end{tabular}

Postoperative comparisons of non-normally and normally distributed variables in three groups (prostate gland $<45 \mathrm{ml},>45 \mathrm{ml}$ and larger than $60 \mathrm{ml}$ ) are displayed in Table 3 and Table 4, respectively. Perioperative results showed no statistical significance among the groups in terms of catheterization days (median 3 days; $p=0.37$ ), the hospitalization length (median 3 days; $p=0.269$ ), estimated blood loss or complications. However, the greater the prostate volume, the greater the volume of irrigation fluid, the amount of resected prostate and operative times. Most of the cases underwent spinal block before operation. During the follow-up, PSA, Qmax, PVR, and average flow rate were significantly different 
Table 3. Postoperative comparison of non-normally distributed variables in three groups.

\begin{tabular}{|c|c|c|c|c|c|c|c|}
\hline \multirow{2}{*}{ Variables } & \multicolumn{2}{|c|}{ Prostate volume $\leq 45 \mathrm{ml}(\mathrm{n}=89)$} & \multicolumn{2}{|c|}{ Prostate volume $>45 \mathrm{ml}(\mathrm{n}=39)$} & \multicolumn{2}{|c|}{ Prostate volume $\geq 60 \mathrm{ml}(\mathrm{n}=34)$} & \multirow{2}{*}{$p$-value } \\
\hline & Median & IQR (Q3 - Q1) & Median & IQR (Q3 - Q1) & Median & IQR (Q3 - Q1) & \\
\hline Hospital stay & 3 & $1(4.0-3.0)$ & 3 & $0(3.0-3.0)$ & 3 & $1(4.0-3.0)$ & 0.269 \\
\hline Irrigate vol (ml): In & 11,900 & $8000(16,000-8000)$ & 18,400 & $18400(23,500-13,250)$ & 23,000 & $12750(31,750-19,000)$ & $0.000^{*}$ \\
\hline Irrigate vol (ml): Out & 11,200 & $7600(15,600-8000)$ & 17,700 & $10600(23,300-12,700)$ & 22,450 & $13650(31,950-18,300)$ & $0.000^{*}$ \\
\hline Prostate resected (g) & 6.00 & $5.5(10-4.5)$ & 10.00 & $9.0(15-6)$ & 20.00 & $20.0(30-10)$ & $0.000^{*}$ \\
\hline BUN & 14 & $6.0(17-11)$ & 14 & $6.0(17-11)$ & 14 & $4.0(16-12)$ & 0.754 \\
\hline Creatinine & 1.05 & $0.29(1.19-0.9)$ & 1.08 & $0.32(1.32-1.00)$ & 1.085 & $0.36(1.24-0.88)$ & 0.498 \\
\hline Albumin & 40.45 & $3.40(41.9-38.5)$ & 39.45 & $4.20(42.3-38.1)$ & 35.6 & $5.10(39.6-34.5)$ & 0.061 \\
\hline Operative time & 75 & $30(90-60)$ & 90 & $25(100-75)$ & 95 & $50(130-80)$ & $0.008^{\star}$ \\
\hline $\begin{array}{c}\text { Indwelling } \\
\text { catheterization time } \\
\text { (days) }\end{array}$ & 3 & $1(4-3)$ & 3 & $0.5(3.0-2.5)$ & 3 & $1.5(3.5-2.0)$ & 0.371 \\
\hline Estimated blood loss & 30 & $90(95-10)$ & 50 & $100(120-20)$ & 100 & $175(200-25)$ & 0.071 \\
\hline
\end{tabular}

Table 4. Postoperative comparison of normally distributed variables in three groups.

\begin{tabular}{|c|c|c|c|c|c|c|c|}
\hline \multirow[t]{2}{*}{ Variables } & \multicolumn{2}{|c|}{$\begin{array}{c}\text { Prostate volume } \leq 45 \mathrm{ml} \\
(\mathrm{n}=89)\end{array}$} & \multicolumn{2}{|c|}{$\begin{array}{c}\text { Prostate volume }>45 \mathrm{ml} \\
(\mathrm{n}=39)\end{array}$} & \multicolumn{2}{|c|}{$\begin{array}{l}\text { Prostate volume } \geq 60 \mathrm{ml} \\
(\mathrm{n}=34)\end{array}$} & \multirow[t]{2}{*}{$p$-value } \\
\hline & $\mathbf{N}$ & Percent & $\mathbf{N}$ & Percent & $\mathbf{N}$ & Percent & \\
\hline Anesthesia technique & & & & & & & 0.291 \\
\hline SB & 70 & 22.013 & 30 & 9.434 & 25 & 7.862 & \\
\hline GA & 2 & 0.629 & 2 & 0.629 & 2 & 0.629 & \\
\hline Late complication & & & & & & & 0.723 \\
\hline Stricture urethra & 3 & 0.943 & 2 & 0.629 & 1 & 0.314 & \\
\hline $\mathrm{CBN}$ & 6 & 1.887 & 0 & 0.000 & 0 & 0.000 & \\
\hline Hypotonic bladder & 0 & 0.000 & 0 & 0.000 & 1 & 0.314 & \\
\hline UTI & 0 & 0.000 & 1 & 0.314 & 0 & 0.000 & \\
\hline Surgical risk & & & & & & & 0.312 \\
\hline Unknown surgical risk & 4 & 1.258 & 1 & 0.314 & 0 & 0.000 & \\
\hline Intermediate risk & 1 & 0.314 & 0 & 0.000 & 0 & 0.000 & \\
\hline Long term & 4 & 1.258 & 2 & 0.629 & 0 & 0.000 & \\
\hline Incontinence & 5 & 1.572 & 0 & 0.000 & 1 & 0.314 & 0.207 \\
\hline On ASA & 9 & 2.830 & 3 & 0.943 & 4 & 1.258 & 0.997 \\
\hline Pathological report: prostate cancer & 14 & 4.403 & 2 & 0.629 & 3 & 0.943 & 0.084 \\
\hline
\end{tabular}

$\mathrm{SB}=$ Spinal block; $\mathrm{GS}=$ General Anesthesia; $\mathrm{CBN}$ = Contracture bladder neck; UTI = Urinary tract infection; ASA = Aspirin. 
from pre-operation data $(p<0.005)$. Prostate volume measured by TRUS was not significantly reduced from a median of $42 \mathrm{ml}$ preoperatively to $38.9 \mathrm{ml}$ postoperatively. Table 5 demonstrated the improvement of postoperative parameters at different periods compared with preoperative subscales in five subgroups at baseline and at 24, 36, 48, and 60 months after treatment. Median of PSA, Qmax, PVR and average flow rate before operation were $4.6 \mathrm{ng} / \mathrm{ml}, 11$ $\mathrm{ml} / \mathrm{s}, 60 \mathrm{ml}$ and $5.6 \mathrm{ml} / \mathrm{s}$, respectively. Median of PSA, Qmax, PVR and average flow rate at 60 months after the operation were $0.884 \mathrm{ng} / \mathrm{ml}, 18.8 \mathrm{ml} / \mathrm{s}, 25 \mathrm{ml}$ and $9.85 \mathrm{ml} / \mathrm{s}$, respectively.

Regarding TURP complications (Table 6), transient incontinence (5.87\%),

Table 5. Improvement of Postoperative Parameters at Different Periods Compared with Preoperative subscales in five subgroups at baseline and after 24,36, 48, and 60 months of treatment (Wilcoxon signed-rank test).

\begin{tabular}{|c|c|c|c|}
\hline Variables & Median & IQR (Q3 - Q1) & $p$-value \\
\hline \multicolumn{4}{|l|}{ PSA (ng/ml) } \\
\hline Pre-op; $\mathrm{n}=231$ & 4.600 & $6.370(7.94-1.57)$ & \\
\hline Post-op 24 month; $\mathrm{n}=190$ & 1.315 & $1.710(2.30-0.59)$ & 0.000 \\
\hline Post-op 36 months; $\mathrm{n}=123$ & 1.120 & $2.168(2.21-0.042)$ & 0.000 \\
\hline Post-op 48 months; $\mathrm{n}=61$ & 0.688 & $2.717(2.72-0.003)$ & 0.000 \\
\hline Post-op 60 months; $\mathrm{n}=20$ & 0.884 & $3.020(3.15-0.13)$ & 0.006 \\
\hline \multicolumn{4}{|l|}{ Prostate volume $(\mathrm{ml})$} \\
\hline Pre-op; $\mathrm{n}=162$ & 42.00 & $24.04(56.51-32.47)$ & \\
\hline Post-op 24 month; $\mathrm{n}=212$ & 41.745 & $26.53(56.18-29.65)$ & 0.197 \\
\hline Post-op 36 months; $\mathrm{n}=137$ & 39.30 & $20.57(50.57-30.00)$ & 0.140 \\
\hline Post-op 48 months; $\mathrm{n}=81$ & 36.80 & $20.99(49.62-28.63)$ & 0.062 \\
\hline Post-op 60 months; $\mathrm{n}=38$ & 38.920 & $19.64(46.97-27.33)$ & 0.036 \\
\hline \multicolumn{4}{|l|}{$\mathrm{Qmax}(\mathrm{ml} / \mathrm{s})$} \\
\hline Pre-op; $\mathrm{n}=228$ & 11.00 & $9.10(16.70-7.60)$ & \\
\hline Post-op 24 month; $\mathrm{n}=94$ & 12.90 & $9.20(17.80-8.60)$ & 0.080 \\
\hline Post-op 36 months; $\mathrm{n}=98$ & 17.10 & $13.90(25.30-11.40)$ & 0.000 \\
\hline Post-op 48 months; $\mathrm{n}=71$ & 16.50 & $13.10(22.50-9.40)$ & 0.004 \\
\hline Post-op 60 months; $\mathrm{n}=190$ & 18.80 & $12.60(26.10-13.50)$ & 0.000 \\
\hline \multicolumn{4}{|l|}{ Residual volume (ml) } \\
\hline Pre-op; $\mathrm{n}=228$ & 60.00 & $104.50(132.50-28.00)$ & \\
\hline Post op 24 month; $\mathrm{n}=94$ & 35.00 & $60.00(75.00-15.00)$ & 0.004 \\
\hline Post op 36 months; $\mathrm{n}=98$ & 35.00 & $55.00(70.00-15.00)$ & 0.000 \\
\hline Post op 48 months; $\mathrm{n}=71$ & 20.00 & $41.00(51.00-10.00)$ & 0.000 \\
\hline Post op 60 months; $\mathrm{n}=190$ & 25.00 & $38.00(53.00-15.00)$ & 0.000 \\
\hline \multicolumn{4}{|l|}{ Average flow $(\mathrm{ml} / \mathrm{s})$} \\
\hline Pre-op; $\mathrm{n}=228$ & 5.600 & $4.80(8.40-3.60)$ & \\
\hline Post op 24 month; $\mathrm{n}=94$ & 6.500 & $3.70(8.20-4.50)$ & 0.927 \\
\hline Post op 36 months; $\mathrm{n}=98$ & 8.950 & $6.50(12.10-5.60)$ & 0.000 \\
\hline Post op 48 months; $\mathrm{n}=71$ & 7.90 & $7.40(12.50-5.10)$ & 0.010 \\
\hline Post op 60 months; $\mathrm{n}=190$ & 9.85 & $6.40(13.50-7.10)$ & 0.000 \\
\hline
\end{tabular}


Table 6. Postoperative Adverse Events $(\mathrm{N}=318)$.

\begin{tabular}{ccc}
\hline & $\mathrm{N}$ & $\%$ \\
\hline Early postoperative complication & & \\
Transient Incontinence & 19 & 5.87 \\
Urinary tract infection & 8 & 2.5 \\
Urinary retention/catheterization & 5 & 1.57 \\
Late postoperative complication & & \\
Contracture of Bladder neck & 14 & 4.40 \\
Urethral stricture & 13 & 4.09 \\
Recurrence BPH & 9 & 2.83 \\
Hypotonic bladder & 2 & 0.62 \\
Erectile dysfunction & 25 & 7.8 \\
\hline
\end{tabular}

urinary tract infection (2.5\%), urinary retention/catheterization (1.57\%), contracture of bladder neck (4.4\%), urethral strictures (4.09\%), recurrence of BPH (2.83\%), hypotonic bladder (0.6\%) and erectile dysfunction (7.8\%) were observed. Neither suffering from TUR syndrome nor receiving blood transfusion were reported during bipolar TURP in this study. Interestingly, no complications for patients on ongoing OA were reported.

\section{Discussion}

Endoscopic management of BPH is based on resection, vaporization, or enucleation [15]. M-TURP was considered the gold standard for the management of bladder outlet obstruction due to BPH [10]. Later, B-TURP showed similar effect and safety in patients with BPH compared with those who underwent M-TURP. In BPH larger than $60 \mathrm{ml}$, a significant difference between the M-TURP and $\mathrm{B}$-TURP groups was the greater decrease in serum sodium levels in the M-TURP group [16].

However many studies demonstrated that the issue of the benefit of B-TURP was, to some extent, controversial [7] [17]. Ahmad et al. reported that the duration of the resection and operating time was shorter in M-TURP than B-TURP and suggested urologists save time by using M-TURP [7]. Transurethral plasmakinetic enucleation and resection of the prostate (TUERP) is superior to B-TURP in the management of large volume BPH in terms of efficacy and safety, but needs to be validated in further prospective, randomized, controlled studies [18]. A steep operative learning curve may be the main obstacle to the widespread use of TUERP [19].

In the present study, a significant constant and gradual improvement over time after B-TURP was observed in the post-operative PSA, average flow rate, Qmax and PVR in all groups with significant difference $(p<0.005)$ at base line and after 24, 36, 48 and 60 months of follow-up. These results were statistically significant compared to the baseline values, when compared with one another, 
and were maintained throughout the whole follow-up period, which is similar to other published data [5] [10].

For complications, secondary bladder neck sclerosis represents one of the more frequent complications following endoscopic, open, and other forms of minimally invasive prostate surgery (e.g., radical prostatectomy, TURP, HoLEP, radiotherapy, HIFU) [20]. Most of the urethral strictures after B-TURP occurred at the bulbar urethra and may be linked to a slow resection rate [21]. In our study, the urethral stricture rate of $4.0 \%$ after B-TURP in this long term study of 60 months is comparable to previous series [21].

In the contemporary B-TURP series, no TUR syndrome was found which confirmed that TUR syndrome is nowadays a clinical rarity [4]. Moreover, secondary hemorrhage after B-TURP and complications of patients on ongoing oral anticoagulation were not found in our study. We believe that many complications can be avoided by a proper resection technique. The main limitation of this study was that it was a retrospective review and small sample size.

The prevalence of erectile dysfunction in Thai males aged $40-70$ years old is $42.18 \%$ [22]. In our series with the mean age 69.45 years, the incidence of erectile dysfunction was $7.8 \%$. It seems that B-TURP did not increase erectile dysfunction.

\section{Conclusion}

Our study confirms that B-TURP in patients' LUTS/BPH provides durable and comparable efficacy at 60 months follow up and is suitable for any prostate size.

\section{Acknowledgements}

We wish to thank Mr. Terry King for English proof-reading, Miss Kornkanok Somoonpun for help with data search and Pattawia Chokrua for data analysis.

\section{References}

[1] Dhingra, N. and Bhagwat, D. (2011) Benign Prostatic Hyperplasia: An Overview of Existing Treatment. Indian Journal of Pharmacology, 43, 6-12. https://doi.org/10.4103/0253-7613.75657

[2] Xie, C.Y., Zhu, G.B., Wang, X.H. and Liu, X.B. (2012) Five-Year Follow-Up Results of a Randomized Controlled Trial Comparing Bipolar Plasmakinetic and Monopolar Transurethral Resection of the Prostate. Yonsei Medical Journal, 53, 734-741. https://doi.org/10.3349/ymj.2012.53.4.734

[3] Al-Rawashdah, S.F., Pastore, A.L., Salhi, Y.A., Fuschi, A., Petrozza, V., Maurizi, A., et al. (2017) Prospective Randomized Study Comparing Monopolar with Bipolar Transurethral Resection of Prostate in Benign Prostatic Obstruction: 36-Month Outcomes. World Journal of Urology, 35, 1595-1601.

https://doi.org/10.1007/s00345-017-2023-7

[4] Fullhase, C. (2016) Die transurethrale Resektion der Prostata [Transurethral Resection of the Prostate]. Der Urologe, 55, 1433-1439.

https://doi.org/10.1007/s00120-016-0243-x

[5] Karadeniz, M.S., Bayazit, E., Aksoy, O., Salviz, E.A., Tefik, T., Sanli, O., et al. (2016) 
Bipolar versus Monopolar Resection of Benign Prostate Hyperplasia: A Comparison of Plasma Electrolytes, Hemoglobin and TUR Syndrome. SpringerPlus, 5, 1739. https://doi.org/10.1186/s40064-016-3407-7

[6] Bozzini, G., Albersen, M., Otero, J.R., Margreiter, M., Cruz, E.G., Mueller, A., et al. (2016) Delaying Surgical Treatment of Penile Fracture Results in Poor Functional Outcomes: Results from a Large Retrospective Multicenter European Study. European Urology Focus, in press. https://doi.org/10.1016/j.euf.2016.02.012

[7] Ahmad, M., Khan, H., Masood, I.A., Masood, W. and Malik, A. (2016) Comparison of Bipolar and Monopolar Cautry Use in Turp for Treatment of Enlarged Prostate. Journal of Ayub Medical College, Abbottabad, 28, 758-761.

[8] Liu, Z., Li, Y.W., Wu, W.R. and Lu, Q. (2017) Long-Term Clinical Efficacy and Safety Profile of Transurethral Resection of Prostate versus Plasmakinetic Resection of the Prostate for Benign Prostatic Hyperplasia. Urology, 103, 198-203. https://doi.org/10.1016/j.urology.2017.02.006

[9] Abou-Taleb, A., El-Shaer, W., Kandeel, W., Gharib, T. and Elshaer, A. (2017) Bipolar Plasmakinetic Enucleoresection of the Prostate: Our Experience with $245 \mathrm{~Pa}$ tients for 3 Years of Follow-Up. Journal of Endourology, 31, 300-306. https://doi.org/10.1089/end.2016.0746

[10] Madduri, V.K., Bera, M.K. and Pal, D.K. (2016) Monopolar versus Bipolar Transurethral Resection of Prostate for Benign Prostatic Hyperplasia: Operative Outcomes and Surgeon Preferences, a Real-World Scenario. Urology Annals, 8, 291-296. https://doi.org/10.4103/0974-7796.184900

[11] Rassweiler, J., Teber, D., Kuntz, R. and Hofmann, R. (2006) Complications of Transurethral Resection of the Prostate (TURP)-Incidence, Management, and Prevention. European Urology, 50, 969-980. https://doi.org/10.1016/j.eururo.2005.12.042

[12] Yee, C.H., Wong, J.H., Chiu, P.K., Teoh, J.Y., Chan, C.K., Chan, E.S., et al. (2016) Secondary Hemorrhage after Bipolar Transurethral Resection and Vaporization of Prostate. Urology Annals, 8, 458-463. https://doi.org/10.4103/0974-7796.192110

[13] Becker, B., Knipper, S., Gross, A.J. and Netsch, C. (2017) Current Management in Transurethral Therapy of Benign Prostatic Obstruction in Patients on Oral Anticoagulation: A Worldwide Questionnaire. Journal of Endourology, 31, 163-168. https://doi.org/10.1089/end.2016.0627

[14] Davis, N.F., Torregiani, W. and Thornhill, J. (2016) Osteitis Pubis after Standard Bipolar TURP Surgery: Insight into Aetiology, Diagnosis, Management and Prevention of This Rarity. BMJ Case Reports, 2016, bcr2015212420.

[15] Cornu, J.N. (2016) Bipolar, Monopolar, Photovaporization of the Prostate, or Holmium Laser Enucleation of the Prostate: How to Choose What's Best? Urologic Clinics of North America, 43, 377-384. https://doi.org/10.1016/j.ucl.2016.04.006

[16] Demirdag, C., Citgez, S., Tunc, B., Simsekoglu, F., Can, G. and Onal, B. (2016) The Clinical Effect of Bipolar and Monopolar Transurethral Resection of the Prostate More than 60 Milliliters. Urology, 98, 132-137.

https://doi.org/10.1016/j.urology.2016.08.008

[17] De Sio, M., Autorino, R., Quarto, G., Damiano, R., Perdona, S., Lorenzo, G.D., et al. (2006) Gyrus Bipolar versus Standard Monopolar Transurethral Resection of the Prostate: A Randomized Prospective Trial. Urology, 67, 69-72. https://doi.org/10.1016/j.urology.2005.07.033

[18] Wei, Y., Xu, N., Chen, S.H., Li, X.D., Zheng, Q.S., Lin, Y.Z., et al. (2016) Bipolar Transurethral Enucleation and Resection of the Prostate versus Bipolar Resection of 
the Prostate for Prostates Larger than 60gr: A Retrospective Study at a Single Academic Tertiary Care Center. International Brazilian Journal of Urology, 42, 747-756. https://doi.org/10.1590/S1677-5538.IBJU.2015.0225

[19] Yu, Y., Lou, G., Shen, C., Guan, S., Wang, W. and Yang, B. (2017) Technical Aspects of Transurethral Plasmakinetic Enucleation and Resection of the Prostate for benign Prostatic Hyperplasia. Minimally Invasive Therapy and Allied Technologies, 26, 44-50. https://doi.org/10.1080/13645706.2016.1227851

[20] Rassweiler, J.J., Weiss, H., Heinze, A., Elmussareh, M., Fiedler, M. and Goezen, A.S. (2017) Blasenhalssklerose nach Prostataeingriffen [Bladder Neck Sclerosis Following Prostate Surgery: Which Therapy When]? Der Urologe, 56, 1129-1138. https://doi.org/10.1007/s00120-017-0431-3

[21] Tan, G.H., Shah, S.A., Ali, N.M., Goh, E.H., Singam, P., Ho, C.C.K., et al. (2017) Urethral Strictures after Bipolar Transurethral Resection of Prostate May Be Linked to Slow Resection Rate. Investigative and Clinical Urology, 58, 186-191. https://doi.org/10.4111/icu.2017.58.3.186

[22] Permpongkosol, S., Kongkakand, A., Ratana-Olarn, K., Tantiwong, A., Tantiwongse, K. and The Thai Erectile Dysfunction Epidemiological Study Group (2008) Increased Prevalence of Erectile Dysfunction (ED): Results of the Second Epidemiological Study on Sexual Activity and Prevalence of ED in Thai Males. The Aging Male, 11, 128-133. https://doi.org/10.1080/13685530802278128 